\title{
The microdetermination of biological copper with oxalyldihydrazide
}

\author{
R. N. BEALE AND D. CROFT \\ From the Institute of Clinical Pathology and Medical Research, \\ Department of Public Health, Sydney, Australia
}

SYNOPSIS Methods are described for the determination of microgram quantitites of biologicas copper in aqueous medium as the intensely coloured oxalyldihydrazide-acetaldehyde comple? (molar extinction coefficient 23,000 to 23,500 ).

The methods are applicable on a routine basis to any biological material, in particular to serum $\dot{w}_{i}^{\dot{\omega}}$ urine, or tissues, such as liver, brain, or kidney. In the case of urine a simple semi-quantitative screening method is also described. For quantitative work copper is liberated from serum by acidg extraction and protein precipitation, and from urine and tissues by a rapid wet-ashing procedure. Recoveries of added copper from urine are quantitative. Precision is high although day-to-dax control with standards and blanks is desirable. The methods are applied in an investigation of the diurnal variations in a normal man and in two cases of Wilson's disease.

Various workers have described the use of oxalyldihydrazide and acetaldehyde for the colorimetric determination of microgram quantities of biological copper. In 1956 Gran showed that in aqueous ammoniacal solution these reagents gave an intense blue-red colour with cupric ion, with a relative light absorption about three times that of the copperdiethyldithiocarbamate complex in organic solvents. Since then oxalyldihydrazide and acetaldehyde have been used, for example, in investigations of sea water (Bowles and Nicks, 1961), enzymes (Stark and Dawson, 1958), and serum (Summers, 1960). The sensitivities of the various methods described differ, the maximal molar extinction coefficients of the coloured complex ranging from 22,000 to 29,500 , with great variation in the recommended time for colour development ( 20 minutes to 18 hours).

In this publication we present methods which were established for clinical purposes and which apply to any biological material, in particular, serum, urine, and such tissues as liver, kidney, and brain. We have worked out conditions for maximum sensitivity and for colour development under simplified and reproducible conditions. The methods are considered suitable for routine or occasional application in the average clinical laboratory.

\section{REAGENTS AND APPARATUS}

All reagents consist of, or are made from, best quality Received for publication 11 September 1963. materials of analytical grade. Ion-free water is usec throughout. Constant boiling hydrochloric acid is madø by distillation of diluted acid. Trichloracetic aci\$ (boiling point $\sim 196^{\circ} \mathrm{C}$.) is purified if necessary by distill ation at normal pressures in all-glass apparatus fitted with an air condenser. Nitric acid S.G. 1.42 may be similarly purified if necessary, but with a water-cooled condenser. All glassware is hydrochloric acid-washed In addition, flasks used in the ashing process are pre? treated with boiling ashing mixture. The vessel for the dilute copper standard is treated with cetyltrimethy? ammonium bromide (Cetavlon) to prevent adsorption of copper ions and then washed with water.

2M HYDROCHLORIC ACID Dilute $164 \mathrm{ml}$. of constan boiling azeotrope $(760 \mathrm{~mm}$. pressure) to 1 litre with wates and mix.

TRICHLORACETIC ACID $10 \%$

AMMONIA S.G. $\mathbf{0} \cdot 880$

OXALYLDIHYDRAZIDE $1 \%$ IN $0.5 \mathrm{M}$ HYDROCHLORIC ACIDO Store at $5^{\circ} \mathrm{C}$. This keeps for at least a month. The solif is easily prepared by Gran's method. Dissolve $7 \cdot 3 \mathrm{~g}$. of ethyl oxalate (B.D.H. reagent grade) in $40 \mathrm{ml}$. of ethan 69 (95 to $100 \%$ ) and $2.5 \mathrm{~g}$. of hydrazine monohydrate in $15 \mathrm{ml}$. of ethanol. Warm the solutions and mix. Place in the refrigerator for an hour. Filter the crystals on aס fritted glass suction funnel and wash with a little colळ ethanol. Recrystallize them from boiling water.

ACETALDEHYDE $40 \%$ Dilute $40 \mathrm{ml}$. ice-cold acetaldehyd民 (very volatile) to $100 \mathrm{ml}$. with ice-cold water. Store aP 
$5^{\circ} \mathrm{C}$. This reagent is stable apart from slight losses of acetaldehyde.

2M AMMONIUM CHLORIDE IN 9M AMMONIA Dissolve $107 \mathrm{~g}$. of ammonium chloride in water and make up to $500 \mathrm{ml}$. with that solvent; add $500 \mathrm{ml}$. of ammonia S.G. $0 \cdot 880$. Mix and store at $5^{\circ} \mathrm{C}$.

\section{PERCHLORIC ACID $70 \%$}

COPPER STANDARD $(5 \mu \mathrm{g}$. $\mathrm{Cu} / \mathrm{ml}$.) Make a $500 \mu \mathrm{g}$. $\mathrm{Cu} / \mathrm{ml}$. standard by dissolving $0 \cdot 1964 \mathrm{~g}$. copper sulphate pentahydrate in $0 \cdot 1 \mathrm{~N}$ sulphuric acid and diluting to $100 \mathrm{ml}$. with the acid. Dilute this solution 1 in 100 with water for the working standard.

NITRIC ACID, CONCENTRATED, S.G. $1 \cdot 42$

SULPHURIC ACID, CONCENTRATED, S.G. 1·84

\section{METHOD FOR SERUM}

To $1 \mathrm{ml}$. of serum add $1 \mathrm{ml}$. of $2 \mathrm{M}$ hydrochloric acid, with shaking; mix well and allow to stand at room temperature for 10 minutes. Then add $1 \mathrm{ml}$. of $10 \%$ trichloracetic acid likewise and let stand for three minutes. Centrifuge. Take $2 \mathrm{ml}$. of supernatant and mix with $0.5 \mathrm{ml}$. ammonia buffer. Add $0.2 \mathrm{ml}$. of oxalyldihydrazide reagent and $\mathrm{mix}$, then $0.3 \mathrm{ml}$. of acetaldehyde reagent and mix again. Incubate for 11 minutes at $60^{\circ} \mathrm{C}$. and immediately cool the tubes in cold running water. For the copper standards take $0.2 \mathrm{ml}$. and $0.4 \mathrm{ml}$. of the $5 \mu \mathrm{g} . / \mathrm{ml}$. working standard and dilute each to $1 \mathrm{ml}$. with water. Then proceed as for serum, but omitting centrifugation; take a $2 \mathrm{ml}$. portion as for serum. Make a blank by using $1 \mathrm{ml}$. of water in place of $1 \mathrm{ml}$. of serum and then proceed as for the standard or the serum.

Colorimeter readings are made against the blank at $542 \mathrm{~m} \mu$ or with an appropriate filter such as the Ilford 625 , yellow-green. The calculation or the serum level is obvious.

\section{METHOD FOR URINE}

PRELIMINARY SEMI-QUANTITATIVE SCREENING To $10 \mathrm{ml}$. of slightly acid urine add $1 \mathrm{ml}$. of concentrated hydrochloric acid, and after 10 minutes at room temperature add $0.3 \mathrm{ml}$. of $1 \%$ oxalyldihydrazide, $0.5 \mathrm{ml}$. of $40 \%$ acetaldehyde, and $2 \mathrm{ml}$. of ammonia buffer. Make up a blank as for the test but omit the addition of oxalyldihydrazide. For an internal standard add $4 \mu \mathrm{g}$. copper to $10 \mathrm{ml}$. of urine, and then proceed as before. Incubate all tubes at $60^{\circ} \mathrm{C}$. for 11 minutes. Cool, centrifuge or filter, and observe the colours.

Normal urines show no visible increase over that in the blank. In Wilson's disease, particularly in untreated cases, marked colour is evident in the test and the amount of copper may be estimated semi-quantitatively by means of the internal standard. In nephrosis or cirrhosis of the liver some increase may be seen.

QUANTITATIVE ANALYSIS For analysis of a normal urine $30 \mathrm{ml}$. is required. In cases of Wilson's disease, cirrhosis of the liver, or nephrosis, $10 \mathrm{ml}$. of urine is usually sufficient. In either case, evaporate the urine to low bulk with $0.5 \mathrm{ml}$. concentrated nitric acid in a 100 to $200 \mathrm{ml}$. round-bottomed, long-necked flask of good quality borosilicate glass. Use a glass bead to prevent bumping and heat until all the liquid has evaporated and only a partly charred mass remains. Allow the flask to cool somewhat, then for $30 \mathrm{ml}$. urine add in order, $2 \mathrm{ml}$. of concentrated nitric acid, $0.6 \mathrm{ml}$. of concentrated sulphuric acid, and finally $0.4 \mathrm{ml}$. of perchloric acid. For $10 \mathrm{ml}$. of urine, use half these quantities.

Next heat moderately until the bulk of the nitric acid has disappeared, and then fairly strongly until the charred residue is oxidized. It is seldom necessary to add more nitric acid and perchloric acids. Continue heating until the bulk of the nitric and chlorine oxides have disappeared but not so strongly that the sulphuric acid is lost as sulphur trioxide. Then allow the flask to cool, and rotate it so that the bead does not become enmeshed eventually in a solid lump of the clear phosphate-sulphate glass. Practically all ashings proceed quickly and smoothly. Next add $4.5 \mathrm{ml}$. water down the walls of the flask and warm it to dissolve as much residue as possible. Cool and add $3 \mathrm{ml}$. ammonia-ammonium chloride. The solution should then be strongly alkaline. Add $0.3 \mathrm{ml}$. of oxalyldihydrazide reagent and $0.5 \mathrm{ml}$. of acetaldehyde reagent, mixing after each addition. Put the flask in a $60^{\circ} \mathrm{C}$. water bath for 11 minutes and then cool in running water. If preferred, the contents of the flasks may be transferred to copper-free test-tubes for incubation. Centrifuge or filter the contents to remove phosphates and other insoluble substances.

Prepare two blanks. For a 'method' blank evaporate appropriate amounts of nitric, sulphuric, and perchloric acids to low bulk and then continue as for the ashed urine, and for a 'standard' blank take $0.5 \mathrm{ml}$. of concentrated sulphuric acid and then proceed as for the ashed urine. Prepare a standard by measuring into a tube $0.8 \mathrm{ml}$. of dilute copper reagent $(4 \mu \mathrm{g} . \mathrm{Cu}), 0.5 \mathrm{ml}$. of concentrated sulphuric acid, and $3.7 \mathrm{ml}$. of water, and then proceed as for the aqueous solution of the ashed urine. Read the tests and standard, all in duplicate preferably, against their appropriate blanks as for the determination of serum copper.

\section{EXPERIMENTAL}

PREPARATION OF SPECIMENS FOR CHELATE FORMATION There is no difficulty in obtaining ionic copper from serum, since Gubler, Lahey, Ashenbrucker, Cartwright, and Wintrobe (1952) showed that merely standing the serum at room temperature with suitable acids will liberate all the copper. Heating was contraindicated.

Liberation of copper from urine components proved a more difficult matter. We made numerous attempts to extract the copper with dithizone or oxine using a variety of solvents and different $p \mathrm{H}$ values. Recoveries of added copper were invariably poor. Total wet ashing using a highly oxidizing medium as described under 'Method' was eventually found to be quite satisfactory. Smooth oxidation of carbonaceous matter occurred almost invariably and usually no further additions of oxidant were necessary. 
Small portions of wet tissue were dealt with in the same way as urine, without the necessity for grinding or mincing.

NATURE AND CONCENTRATION OF REACTANTS We investigated various alkalis, aldehydes, and ketones in order to assess the sensitivity and speed of reaction in forming the coloured copper chelate. Ammonia was the only satisfactory alkali, particularly in combination with ammonium chloride, to give some degree of buffering. Oxalyldihydrazide is sparingly soluble in common solvents $(0.3 \%$ in water) and has previously been used at low concentrations. However, it dissolves more readily in dilute acid to give a reasonably stable reagent. The higher concentration leads to faster chelate formation. Acetaldehyde is the most satisfactory of the carbonyl compounds. An excess is essential for formation of the red-blue colour. With low concentrations of aldehyde a different blue colour forms, changing to the usual bluered on addition of excess acetaldehyde. The blue complex has a much lower molar extinction coefficient than that of the red-blue one at $542 \mu$.

TIME AND TEMPERATURE OF REACTION When we developed the colour at room temperature (apart from the warming which occurred on mixing the reagents), complex was still forming after 30 minutes. In further experiments with incubation at $37^{\circ} \mathrm{C}$. for 25 minutes followed by cooling, the colour continued to increase slowly for the next 21 hours. Incubation at $60^{\circ} \mathrm{C}$. for varying periods was next tried. Although this is above the boiling point of acetaldehyde, its solubility in water and the formation of acetaldehyde-ammonia prevent much loss. Under such conditions colour rises to a maximum in 10 to 12 minutes. Continued heating tends to break down the complex. After 15 minutes $97 \%$ of maximum colour remains, dropping to $93.5 \%$ after 25 minutes.

\section{RESULTS AND DISCUSSION}

MOLAR EXTINCTION COEFFICIENTS AND LINEARITY For the serum method we found a mean molar extinction coefficient of about 23,500 and for urinary copper one of about 23,000. This is in reasonably close agreement with the results of Stark and Dawson $\left(\epsilon_{\mathrm{mol}}=22,000\right)$ but considerably lower than Gran's original value of 29,500 . The amount of colour was found to be linear with copper concentration up to the limits of reliability of any particular reading instrument.

REPRODUCIBILITY In earlier work a set of octuplicate standards gave readings of $0.181 \pm 0.005$ optical density units or less than $\pm 3 \%$ extreme variation. Later, when the methods were improved somewhat, quadruplicate standards read $0 \cdot 206 \pm$ 0.003 units for the urine method and $0.412 \pm 0.004$ for the serum method.

Although the reproducibility on any one day is thus satisfactory, we found that both the blanks and the absolute amount of colour per unit of coppero vary slightly from week to week and for this reason we include standards with each determination rather than set up a calibration curve.

RECOVERIES OF COPPER FROM SERUM AND URINE? Gubler et al. (1952) showed that recoveries of copperฉ from plasma by acid extraction and precipitation were excellent, in fact slightly better by $3 \%$ than those obtained by wet ashing. We have assumed; therefore, that for serum the same findings would $\vec{\omega}$ hold. On the other hand, information on recoveries? from urine seems on less sure grounds. Consequently,? we investigated urines from three normal men and from one man with Wilson's disease (Table I).w

\section{T ABLE I}

RECOVERIES OF COPPER ADDED TO URINE

\begin{tabular}{lllll}
$\begin{array}{l}C u \text { in } \\
\text { Aliquot (ug.) }\end{array}$ & $\begin{array}{l}\text { Cu in } \\
\text { Aliquot } \\
\text { Addition } \\
(\mu g .)\end{array}$ & $\begin{array}{l}C u \\
\text { Recovered } \\
(\mu g .)\end{array}$ & $\begin{array}{l}C u \text { Added } \\
(\mu g .)\end{array}$ & $\begin{array}{l}\text { Recovery } \\
(\%)\end{array}$ \\
\hline 0.48 & 4.48 & 4.00 & 4.00 & 100 \\
0.41 & 4.48 & 4.07 & 4.00 & 102 \\
0.38 & 4.35 & 3.97 & 4.00 & 99 \\
12.90 & 17.55 & 4.65 & 5.00 & 93
\end{tabular}

Recoveries of added copper were quantitative for total amounts up to about $5 \mu \mathrm{g}$. In the fourth case we ashed a deliberately large amount of urine with a윽 high copper content, but nevertheless a reasonably? good recovery of added copper ensued. Since totato ashing is used, these results indicate that all of original urinary copper is being determined. Further? more, it is evident that urinary phosphates do not interfere at any stage. None of the cations found in urine would be expected to interfere in the amountso in which they usually occur (Stark and Dawson, 1958).

NORMAL VALUES AND DIURNAL VARIATION No= extensive investigation of normal values has been $N$ made in the present study. Four normal men were examined and their urinary outputs were $21,21,27 \mathrm{~N}$ and $42 \mu \mathrm{g}$. per 24 hours, in keeping with the statement by Varley (1958) that normal values have been tending towards lower levels as methodology has improved.

One of the normal men referred to above was also investigated for possible variation in his copperexcretion over a 24-hour period (Table II). Consider $\frac{\vec{D}}{\mathbb{D}}$ able fluctuations were evident, the rate of output for the overnight period being about three times that of the afternoon to evening period, with other rates

\section{.}




\section{TABLE II}

DIURNAL VARIATIONS IN URINARY COPPER OUTPUT BY A NORMAL MAN

\begin{tabular}{|c|c|c|c|c|c|}
\hline Period & $\begin{array}{l}\text { No. of } \\
\text { Hours }\end{array}$ & $\begin{array}{l}\text { Urine } \\
\text { Volume } \\
\text { (ml.) }\end{array}$ & $\begin{array}{l}\text { Total } \\
\mathrm{Cu} \\
(\mu g .)\end{array}$ & $\begin{array}{l}\text { Cu } \\
\text { Concentration } \\
(\mu g . / 1 .)\end{array}$ & $\begin{array}{l}\text { Output } \\
\text { Rate } \\
\text { ( } \mu g . / h r .)\end{array}$ \\
\hline $\begin{array}{l}7.10 \text { a.m. to } 9.10 \text { a.m. } \\
9.10 \text { a.m. to } 1.42 \text { p.m. } \\
1.42 \text { p.m. to } 7.36 \text { p.m. } \\
7.36 \text { p.m. to } 10.10 \text { p.m. } \\
10.10 \text { p.m. to } 7.10 \text { a.m. }\end{array}$ & $\begin{array}{l}2 \cdot 0 \\
4 \cdot 53 \\
5 \cdot 9 \\
2 \cdot 57 \\
9 \cdot 0\end{array}$ & $\begin{array}{r}99 \\
212 \\
230 \\
166 \\
368\end{array}$ & $\begin{array}{r}1 \cdot 70 \\
2 \cdot 93 \\
2 \cdot 48 \\
2 \cdot 24 \\
11 \cdot 96\end{array}$ & $\begin{array}{l}17 \cdot 2 \\
13 \cdot 8 \\
10 \cdot 8 \\
13 \cdot 5 \\
32 \cdot 5\end{array}$ & $\begin{array}{l}0.85 \\
0.65 \\
0.42 \\
0.87 \\
1.33\end{array}$ \\
\hline
\end{tabular}

falling between these extremes. Obviously, 24-hour collections are necessary, particularly if diseases other than hepatolenticular degeneration are being considered.

INVESTIGATIONS IN WILSON'S DISEASE Two cases were followed. The first was that of a man of 19 in whom the disease was already advanced and who showed the Kayser-Fleischer rings, marked mental deterioration accompanied by euphoria, slurred speech, and rigidity and spasm. There was marked cirrhosis with a grossly abnormal distribution of serum proteins on electrophoresis. The albumin-globulin ratio was $0 \cdot 8: 1$. The serum copper level was normal on one occasion at $70 \mu \mathrm{g} . \%$ and high on two others at 133 and $150 \mu \mathrm{g} . \%$ because of intercurrent infection. Serum copper oxidase activity was normal on the one occasion on which it was estimated. The urinary copper output was $950 \mu \mathrm{g}$./day on one occasion and 1,024 $\mu \mathrm{g}$./litre on another (incontinence prevented the collection of a 24-hour specimen). The patient subsequently died and some of the organs were examined for copper content. The amounts of copper found per gram of wet tissue were as follows: liver, $225 \mu \mathrm{g}$; brain, $54 \mu \mathrm{g}$.; kidney, $83 \mu \mathrm{g}$. ; brain (parietal cortex), $49 \mu \mathrm{g}$.; skin, $2 \mu \mathrm{g}$. The value for kidney was $377 \mu \mathrm{g} . / \mathrm{g}$. when based on dry weight of tissue. In normal man the approximate mean copper contents per gram dry weight are: for liver, $25 \mu \mathrm{g}$.; for brain, $18 \mu \mathrm{g}$. ; for kidney, $18 \mu \mathrm{g}$.

The second case was that of a man of 27 who showed less advanced symptoms; there was no apparent mental deterioration but Kayser-Fleischer rings were clearly present. The urinary output was determined before treatment began. On the first occasion (day 1) it was $2,110 \mu \mathrm{g}$. Cu/24 hours and on the second (day 15), 2,310 $\mu \mathrm{g}$./day. Intermittent treatment with B.A.L. and potassium sulphide followed. By day 22 there was a marked drop in output to $463 \mu \mathrm{g}$./day; successive determinations were $458,890,800$, and $1,100 \mu \mathrm{g}$. for days $33,41,44$, and 47 . Therapy is at present continuing.

It is evident that determinations of urinary copper are considerably more useful than those for serum, since, in the former case, the distinction between normals and abnormals is so much greater. Furthermore, the urinary output seems to be relatively little affected by complications such as intercurrent infections which, if unsuspected, can lead to misinterpretation of serum copper analyses.

This paper is published with the approval of the Director, State Health Services, New South Wales Department of Public Health.

\section{REFERENCES}

Bowles, P. F., and Nicks, P. F. (1961). Analyst, 86, 483.

Gran, G. (1956). Analyt. chim. Acta, 14, 150.

Gubler, C. J., Lahey, M. E., Ashenbrucker, H., Cartwright, G. E., and Wintrobe, M. M. (1952). J. biol. Chem., 196, 209.

Stark, G. R., and Dawson, C. R. (1958). Analyt. Chem., 30, 191.

Summers, Ruby M. (1960). Ibid., 32, 1903.

Varley, H. (1958). Practical Clinical Biochemistry, 2nd ed., p. 375. Heinemann, London. 